\title{
Novel RGD-lipid conjugate-modified liposomes for enhancing siRNA delivery in human retinal pigment epithelial cells
}

This article was published in the following Dove Press journal:

International Journal of Nanomedicine

25 October 20II

Number of times this article has been viewed

\section{Cheng-Wei Chen' \\ Da-Wen Lu ${ }^{2}$ \\ Ming-Kung Yeh ${ }^{3}$ \\ Chia-Yang Shiau ${ }^{4}$ \\ Chiao-Hsi Chiang ${ }^{1,5}$}

'Graduate Institute of Life Sciences,

${ }^{2}$ Department of Ophthalmology,

Tri-Service General Hospital,

${ }^{3}$ Institution of Preventive Medicine,

${ }^{4} \mathrm{Graduate}$ Institute of Medical

Sciences, ${ }^{5}$ School of Pharmacy,

National Defense Medical Center,

Neihu, Taipei, Taiwan

Video abstract

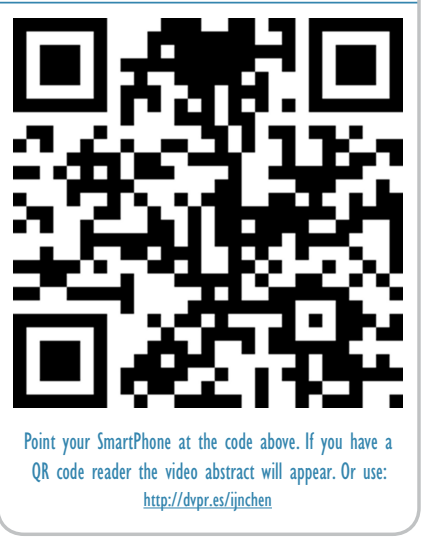

Correspondence: Chiao-Hsi Chiang School of Pharmacy National Defense Medical Center, I6I Minchuan E Rd, Sec 6 Neihu, Taipei I 1490, Taiwan

Tel +886287923100 ext 18894

Fax +886287924838

Email cch@ndmctsgh.edu.tw
Background: Human retinal pigment epithelial cells are promising target sites for small interfering RNA (siRNA) that might be used for the prevention and/or treatment of choroidal neovascularization by inhibiting the expression of angiogenic factor; for example, by downregulating expression of the vascular endothelial growth factor gene.

Methods: A novel functional lipid, DSPE-PEG-RGD, a $\operatorname{Arg}(\mathrm{R})-\mathrm{Gly}(\mathrm{G})-\mathrm{Asp}(\mathrm{D})$ motif peptide conjugated to 1, 2-distearoyl-sn-glycero-3-phosphoethanolamine- $\mathrm{N}$-[maleimide (polyethylene glycol)-2000], was synthesized for the preparation of siRNA-loaded RGD-PEGylated liposomes to enhance uptake of encapsulated siRNA in retinal pigment epithelial cells. Various liposomes, with $1 \mathrm{~mol} \%$ and 5 mol\% PEGylated lipid or $1 \mathrm{~mol} \%$ and 5 mol\% RGD-PEGylated lipid, were fabricated.

Results: Characterization of the liposomes, including siRNA entrapment efficiency, average particle size and $\zeta$-potential, were determined to be as follows: $>96 \%, 129.7 \pm 51$ to $230.7 \pm 60.7 \mathrm{~nm}$, and $17.3 \pm 0.6$ to $32 \pm 1.3 \mathrm{mV}$, respectively. For the in vitro retinal pigment epithelial cell studies, the RGD-PEGylated liposomes had high delivery efficiency with siRNA delivery, about a four-fold increase compared with the PEGylated liposomes. Comparison of the various liposomes showed that the $1 \mathrm{~mol} \%$ RGD-modified liposome had less cytotoxicity and higher siRNA delivery efficiency than the other liposomes. The antibody blocking assay confirmed that uptake of the $1 \mathrm{~mol} \%$ RGD-PEGylated liposome was via integrin receptor-mediated endocytosis in retinal pigment epithelial cells.

Conclusion: The results of this study suggest that RGD-PEGylated liposomes might be useful for siRNA delivery into retinal pigment epithelial cells by integrin receptor-medicated endocytosis.

Keywords: Arg-Gly-Asp, RGD, small interfering RNA, liposome, retinal pigment epithelial cells

\section{Introduction}

Gene therapy is thought to have great potential for treatment of acquired diseases, as well as inherited genetic diseases. ${ }^{1}$ Many human diseases, eg, cancer and neovascularization, have been associated with overexpression of specific genes. The delivery of a normally functioning gene to the nucleus or cytoplasm of malfunctioning cells, may restore the targeted abnormal gene to a normal state. ${ }^{2,3}$ Human retinal pigment epithelial cells play an important role in angiogenesis of the choroid by overexpression of angiogenic factors. Small interfering RNA (siRNA) is a double-stranded structure with 21-23 base pairs that can target its complementary mRNA, thereby hastening mRNA degradation, and inhibiting translation of a targeted gene. ${ }^{4-6}$ With high specificity and easy application, siRNA has gradually replaced more conventional gene 
knockdown techniques for target-specific gene silencing. The ability of siRNA to silence gene expression has become a useful tool for investigating gene function; in addition, it is used in the pharmaceutical industry to develop pharmacological agents. ${ }^{7}$ Thus, retinal pigment epithelial cells might be a promising target site for siRNA used to prevent or treat choroidal neovascularization in patients with agerelated macular degeneration by inhibiting expression of angiogenic factor. However, use of siRNA as a therapeutic agent has been complicated by problems such as poor formulation stability, difficulty penetrating biological barriers, and low delivery efficiency at the target site. Therefore, it is important to develop a delivery system that serves as an effective vector for siRNA and provides optimal delivery to the targeted site. ${ }^{6,8}$

Cationic liposomes are a promising nonviral delivery system, and have been extensively studied for siRNA and plasmid DNA delivery. ${ }^{9}$ The addition of polyethylene glycol (PEG) to the liposomes can decrease reticuloendothelial system recognition, thereby prolonging the circulation time in biological fluids. Although PEGylated liposomes provide a more stable preparation, the steric barrier of the grafted PEG moiety on the surface of the liposomes reduces interaction between the delivery system and the cell surface. Many strategies have been successfully implemented to improve cell delivery efficiency of the PEGylated nanoparticles including transient PEG coating, attachment of targeting ligands at the distal end of PEG moieties, and the incorporation of cell-penetrating peptides. ${ }^{10,11}$ Currently, liposome studies are focusing on targeting delivery to maximize the delivery of the carried therapeutic agent to the targeting site and minimizing potential side effects. The addition of specific antibodies or a biological adhesive cell ligand to the liposome can enhance its binding ability in specific tissues, cells or pathogens, and consequently achieve higher delivery efficiency. For enhancing siRNA delivery into retinal pigment epithelial cells, the ligand of the surface receptors in the retinal pigment epithelial cells might be used to modify the PEGylated lipid of the liposome. Previous studies have shown that integrin receptors are upregulated in ocular neovascularization. Specifically, integrin $\alpha_{v} \beta_{3}$ is overexpressed in the ocular tissues of patients with age-related macular degeneration, whereas, $\alpha_{\mathrm{v}} \beta_{3}$ and $\alpha_{v} \beta_{5}$ are also found in the vascular tissues of patients with proliferative diabetic retinopathy. ${ }^{12}$ Other studies showed that, in retinal pigment epithelial cells, the $\alpha_{\mathrm{v}} \beta_{3}$ and $\alpha_{\mathrm{v}} \beta_{5}$ receptors were expressed at the apical side, while integrin $\alpha_{5} \beta_{1}$ receptors were expressed at the basolateral side. ${ }^{13}$ Expression of $\alpha_{5} \beta_{1}$ integrins on the basolateral side of retinal pigment epithelial cells has been characterized and shown to be important for attachment of cells to Bruch's membrane. Expression of $\alpha_{\mathrm{v}} \beta_{3}$ and $\alpha_{v} \beta_{5}$ integrins at the apical side has been associated with maintenance of diurnal phagocytosis of the shed photoreceptor outer segment fragment. ${ }^{14}$ In order to enhance the delivery of siRNA-loaded liposomes to retinal pigment epithelial cells, liposomes with the integrin receptor ligand might be used to target delivery of siRNA to retinal pigment epithelial cells for the prevention and/or treatment of choroidal neovascularization in patients with age-related macular degeneration. Moreover, peptides with the RGD motif have been shown to bind specifically to $\alpha_{\mathrm{V}}$ - or $\alpha_{5}$ - associated integrins. ${ }^{15,16}$ Thus, modified liposomes with the RGD motif peptide might be constructed to carry siRNA for targeted delivery.

The purpose of this study was to synthesize a functional RGD peptide-lipid conjugate and develop an effective lipid-based gene vector associated with the RGD peptide for targeting integrin receptors and enhancing siRNA delivery to retinal pigment epithelial cells. In addition, the characterization, cytotoxicity, and delivery efficiency of the liposome preparations were investigated.

\section{Materials and methods Chemicals}

A negative control siRNA or FAM-labeled negative control siRNA (having a molecular mass of approximately 13.5 kDa, sense: FAM-5'-UUC-UCC-GAA-CGU-GUCACG-UTT-3' and antisense: 5'-ACG-UGA-CAC-GUUCGG-AGA-ATT-3') were purchased from MDBio Inc (Taipei, Taiwan). All of the lipid materials used, $3 \beta-\left[\mathrm{N}-\left(\mathrm{N}^{\prime}, \mathrm{N}^{\prime}-\right.\right.$ dimethylaminoethane)-carbamoyl] cholesterol (DC-cholesterol), 1,2-dioleoyl-sn-glycero-3-phosphoethanolamine (DOPE), 1,2-distearoyl-sn-glycero-3-phosphoethanolamine$\mathrm{N}$-[carboxy (polyethylene glycol)-2000] [DSPE-PEG(2000) carboxy], and 1,2-distearoyl-sn-glycero-3-phosphoethanolamine-N-[maleimide (polyethylene glycol)-2000] [DSPE-PEG(2000) maleimide] were obtained from Avanti Polar Lipids (Alabaster, AL). The RGD peptide (sequence: H-Gly-Arg-Gly-Asp-Ser-Pro-Lys-Cys-OH, molecular weight, 818.9 Da) was purchased from Yao-Hong Biotechnology Inc (Taipei, Taiwan). CHCA ( $\alpha$-cyano-4-hydroxycinnamic acid) was obtained from Sigma-Aldrich (St Louis, MO). The SYBR Gold, Hoechst 33342, and BODIPY phalloidin dyes were obtained from Invitrogen (Eugene, OR). The MTS reagent, 3-[4, 5-dimethylthiazol-2-yl]-5-(3-carboxymethoxyphenyl)-2(4-sulfophenyl)-2 $H$-tetrazolium, was purchased from Promega Corporation (Madison, WI). Anti-integrin antibodies $\left(\alpha_{\mathrm{v}} \beta_{3}\right.$, MAB1976; $\alpha_{5} \beta_{1}$, MAB1969; $\alpha_{5}$, CBL497) were obtained from 
Chemicon International (Temecula, CA). All other chemicals were pharmaceutical or reagent grade.

\section{Synthesis and identification of DSPE-PEG(2000)-RGD}

RGD peptide-conjugated DSPE-PEG(2000) maleimide [DSPE-PEG (2000)-RGD] was synthesized by modifying a method previously reported. ${ }^{17}$ Briefly, DSPE-PEG(2000) maleimide ammonium salt (molecular weight 2941.61) and RGD peptide were dissolved in a buffer solution $(50 \mathrm{mM}$ triethanolamine hydrochloride, $50 \mathrm{mM}$ sodium phosphate, $150 \mathrm{mM} \mathrm{NaCl}$, and $1 \mathrm{mM}$ EDTA, pH 8). DSPE-PEG(2000) maleimide solution $(2 \mathrm{mM})$ was gently mixed with an equal volume of RGD peptide solution ( $4 \mathrm{mM}$ ) overnight in a glass bottle at $4^{\circ} \mathrm{C}$. The synthesized product was identified by matrix-assisted laser desorption/ionization time-of-flight (MALDI-TOF) mass spectrometry (Bruker Daltonics, Autoflex II TOF/TOF50, Leipzig, Germany).

\section{Preparation of siRNA-loaded liposomes}

PEGylated cationic liposomes, containing DC-cholesterol, DOPE, and DSPE-PEG(2000) carboxy with molar ratios of $50 / 49 / 1$ and 50/45/5, were prepared by the thin-film hydration method according to a method previously reported. ${ }^{18}$ Briefly, the lipids were dissolved in chloroform in a rotary bottle (total lipids $3.6 \mu \mathrm{mol}$ ). After evaporation, a thin lipid film was formed and further dried under a vacuum for eight hours to remove residual solvent. The dry lipid film was hydrated for eight hours using $2.4 \mathrm{~mL}$ sterile phosphatebuffered solution containing siRNA or FAM-labeled siRNA. The dispersion was sonicated for 10 minutes and then passed through a polycarbonate membrane 10 times $(100 \mathrm{~nm}$ pore size) using an extruder (Avanti Polar Lipids, Mini-Extruder, Birmingham, AL). The total lipid concentration of the prepared liposomes was $1.5 \mathrm{mM}$.

\section{Preparation of siRNA-loaded liposomes with RGD peptide modification}

RGD-modified PEGylated cationic liposomes, containing DC-cholesterol, DOPE, and DSPE-PEG(2000)-RGD, with molar ratios of 50/49/1 and 50/45/5, respectively, were prepared. The procedure was the same as described above.

\section{Characterization of siRNA-loaded liposomes}

Particle size

The prepared siRNA-loaded liposomes $(1.5 \mathrm{mM})$ were diluted to $1 \mathrm{mM}$ using an appropriate volume of sterile phosphate-buffered solution ( $\mathrm{pH}$ 7.3). The volume-average hydrodynamic diameter of various siRNA-loaded liposomes was determined by a dynamic light scattering method using a particle analyzer (Horiba Instruments Limited, LB-500, Tokyo, Japan). A laser diode was used for dynamic light scattering, with a LB-550 software system from Horiba Instruments Limited. The apparatus consisted of a digital correlator and a signal processor incorporated in a computer. Measurements were made at $650 \mathrm{~nm}$, at a $90^{\circ}$ angle for the detector (photo multiplier tube). The mean particle size and size distribution of the siRNA-loaded liposomes were obtained for each sample measurement at room temperature.

\section{Zeta potential}

The prepared siRNA-loaded liposomes $(1.5 \mathrm{mM})$ were diluted to $1 \mathrm{mM}$ using an appropriate volume of sterile phosphate-buffered solution ( $\mathrm{pH}$ 7.3). The zeta potential of the siRNA-loaded liposomes was measured by determining the electrophoretic mobility using the zeta potential analyzer (Brookhaven Instruments, ZetaPlus, Long Island, NY) at room temperature. Triplicate measurements were performed for each sample.

\section{Transmission electron microscopy}

For the transmission electron microscopy, the siRNAloaded liposome solution $(8 \mu \mathrm{L})$ was placed on a formvar/ carbon film-coated copper grid, obtained from Ted Pella (Redding, CA). After removing excess sample with filter paper, the sample was air-dried for 10 minutes at room temperature. The siRNA-loaded liposomes were then visualized using $0.5 \%$ uranyl acetate negative staining for 15 seconds at room temperature and imaged on a transmission electron microscope (Hitachi, H-7650, Tokyo, Japan). Images were taken at 50,000 $\times$ magnification.

\section{Entrapment efficiency}

For determination of the entrapment efficiency of the PEGylated liposomes and RGD peptide-modified PEGylated liposomes, the amount of negative control siRNA was quantified in the external phase, according to methods previously reported..$^{19,20}$ The liposomes were spun down at $20,000 \times \mathrm{g}$ for 30 minutes; the supernatants were diluted (if necessary), and stained with SYBR Gold dye and analyzed for siRNA content by measuring the intensity of fluorescence with an enzymelinked immunosorbent assay reader (Biochrom Ltd, Anthos 2010, Cambridge, UK) at $537 \mathrm{~nm}$ against a standard curve. A standard curve was established from analyzing a series of siRNA reference solutions with $200 \mu \mathrm{L}$ measured by an enzyme-linked immunosorbent assay reader, and determined 
fluorescence intensity of $537 \mathrm{~nm}$. The regression equations were as follows: $\mathrm{y}=11.343 \mathrm{x}-221.91$, $\mathrm{r}$ square $=0.9992$. The regression lines had good linearity, ranging from 31.25 to $2000 \mathrm{ng} / \mathrm{mL}$ for siRNA. The entrapment efficiency of the siRNA-loaded liposomes was calculated as the ratio of siRNA used for preparation of the initial mixture as follows: Entrapment efficiency $(\%)=\left(\operatorname{siRNA}_{t}-\right.$ siRNA $\left._{f}\right) /$ siRNA $_{t} \times 100$; where siRNA is the total amount of siRNA used for preparation of the initial mixture and siRNA is $_{\mathrm{f}}$ the free siRNA amount recovered in the supernatant. All the measurements were done in triplicate.

\section{ARPE- 19 cell cultures}

ARPE-19 cells were obtained from the American Tissue Culture Collection and cultured in a 1:1 mixture of Dulbecco's modified Eagle's medium (DMEM) and Ham's F12 with $15 \mathrm{mM}$ HEPES buffer, $2 \mathrm{mM}$ L-glutamine, $56 \mathrm{mM}$ sodium bicarbonate, and 10\% fetal bovine serum. The cells were maintained at $37^{\circ} \mathrm{C}$ in a humidified atmosphere with $5 \%$ $\mathrm{CO}_{2} \cdot{ }^{21}$ Cells in passages 25 to 32 were used in the experiments, and seeding cells were counted in a hemocytometer with Trypan blue staining.

\section{Liposomal cytotoxicity}

ARPE-19 cells were seeded in 96-well plates at a density of $1.6 \times 10^{4}$ cells per well and incubated for 18 hours. Before the MTS assay, cells were washed with phosphate-buffered solution $100 \mu \mathrm{L}$. A $1.5 \mathrm{mM}$ total lipid concentration of the prepared liposomes was diluted to $51.2,12.8$, and $3.2 \mu \mathrm{M}$ with serumfree culture medium. The siRNA-loaded liposomes were then added to $100 \mu \mathrm{L}$ of serum-free culture medium. After four hours, the cells were washed with phosphate-buffered solution $100 \mu \mathrm{L}$, and $100 \mu \mathrm{L}$ of the cultured media was then added. Next, the cells were added to $20 \mu \mathrm{L}$ of MTS and incubated for two hours at $37^{\circ} \mathrm{C}$. An enzyme-linked immunosorbent assay reader, set at $490 \mathrm{~nm}$, was used to read the absorbance of formazan in each well to determine the quantity of mitochondrial dehydrogenases in the viable cells. The percent cell viability was calculated as: cell viability $(\%)=\left[\left(\mathrm{ABS}_{\text {sample }}-\mathrm{ABS}_{\text {blank }}\right) /\right.$ $\left.\left(\mathrm{ABS}_{\text {control }}-\mathrm{ABS}_{\text {blank }}\right)\right] \times 100$, where $\mathrm{ABS}_{\text {sample }}, \mathrm{ABS}_{\text {control }}$, and $\mathrm{ABS}_{\text {blank }}$ represent the absorbance of wells exposed to the liposomal dispersions, treated with serum-free culture medium, and treated with serum-free culture medium but without cells, respectively. ${ }^{22}$

\section{Confocal laser scanning microscopy}

The ARPE-19 cells were seeded in six-well plates using DMEM medium at a density of $2 \times 10^{5}$ cells per well and incubated for
24 hours to achieve $50 \%$ confluence. Before the uptake study, the culture media was removed, and the cells were washed with phosphate-buffered solution. The phosphate-buffered solution was then removed, and the prepared FAM-siRNA loaded liposomes, in $1 \mathrm{~mL}$ of serum-free culture media, were added. After four hours, the cells were washed three times with phosphate-buffered solution. The cells were then fixed with $3.7 \%$ formaldehyde for 10 minutes and washed three times with $1 \mathrm{~mL}$ of phosphate-buffered solution. Finally, cellular permeability was increased by adding $0.1 \%$ Triton for five minutes, and washing three times with $1 \mathrm{~mL}$ of phosphatebuffered solution. The cells were incubated in Hoechst 33342 for five minutes, which was then replaced by BODIPY phalloidin for 20 minutes. Confocal laser scanning microscopy (Jeol Ltd, Leica TCS SP5, Tokyo, Japan) was performed to obtain optical images of the distribution of FAM-siRNA in the ARPE-19 cells. Images obtained from the bottom of the coverslip to the top of the cells were recorded by confocal laser scanning microscopy (CLSM). The number of speckled green fluorescence images of the FAM-siRNA located within the cytoplasm was counted from the Z-series images at every $1 \mu \mathrm{m}$ of depth. For determination of the FAM-siRNA localized within the cell, the number of speckled green fluorescence images counted was divided by total cell number observed in each image. The figure was determined by the distance of the $\mathrm{Z}$-axis from the bottom of the coverslip versus the number of speckled green fluorescence (FAM-siRNA) images counted in the cytoplasm of each cell.

\section{Flow cytometry}

The ARPE-19 cells were seeded in six-well plates using DMEM medium at a density of $3 \times 10^{5}$ cells per well and incubated for 24 hours to achieve $75 \%$ confluence. Before the uptake study, the culture media was removed and the cells were washed with phosphate-buffered solution. FAMsiRNA loaded liposomes in $1 \mathrm{~mL}$ of serum-free culture media were then added. After four hours, the cells were washed three times with phosphate-buffered solution and then detached using $0.05 \%$ trypsin $/ 0.02 \%$ EDTA, washed with phosphate-buffered solution, and resuspended in $1 \mathrm{~mL}$ phosphate-buffered solution for flow cytometric assay. The FAM-siRNA loaded liposome uptake was measured using a flow cytometer (Becton Dickinson, FACScan flow cytometer, Heidelberg, Germany). The ARPE-19 cells were then analyzed at $488 \mathrm{~nm}$ excitation and $530 \mathrm{~nm}$ band-pass filter in the emission path. Forward and side light scatter was used to gate the desired scattered events of the normal cells, dead cells, and cell debris. 


\section{Antibody blocking assay of FAM-siRNA loaded liposomes}

Previous studies have shown that ARPE-19 overexpresses various integrins and serves as an in vitro cell model for gene delivery. ${ }^{23,24}$ In order to confirm that receptor-bearing cells take up the RGD-modified PEGylated liposome, ARPE-19 was incubated with FAM-siRNA-loaded $1 \mathrm{~mol} \%$ RGD-PEGylated liposomes at $37^{\circ} \mathrm{C}$. To determine that specific receptors were used in the uptake of $1 \mathrm{~mol} \%$ RGD-PEGylated liposomes by ARPE-19, the cells were pretreated with antibodies that block $\alpha_{v} \beta_{3}$ (MAB1976), $\alpha_{5} \beta_{1}$ (MAB1969), and $\alpha_{5}$ (CBL497) integrins. All antibodies were used at $5 \mu \mathrm{g} / \mathrm{mL} .{ }^{25}$ The ARPE-19 cells were seeded in six-well plates using DMEM medium at a density of $3 \times 10^{5}$ cells per well and incubated for 24 hours to achieve $75 \%$ confluence. Before treating the FAM-siRNA loaded liposomes, the cells were preincubated separately with $\alpha_{\mathrm{v}} \beta_{3}$ antibody, $\alpha_{5}$ antibody, or $\alpha_{5} \beta_{1}$ antibody, for one hour and then FAM-siRNA loaded liposomes were added. After two hours, the cells were washed three times with phosphate-buffered solution and then detached using $0.05 \%$ trypsin/0.02\% EDTA, washed with phosphate-buffered solution, and resuspended in $1 \mathrm{~mL}$ of phosphate-buffered solution for the flow cytometry assay.

\section{Statistical analysis}

The results are expressed as the mean \pm standard deviation. The Student's $t$-test for the comparisons between two means was used to determine statistical significance. Differences were considered to be significant at $P<0.05$.

\section{Results \\ Synthesis and identification of DSPE-PEG-RGD}

Under the reaction conditions of 12 hours at $4^{\circ} \mathrm{C}, \mathrm{pH} 8$, and gentle mixing, DSPE-PEG(2000)-RGD (molecular weight $3741.69 \mathrm{Da})$ was successfully synthesized using DSPEPEG(2000) maleimide (molecular weight 2922.79 Da) and thiolated RGD peptide (molecular weight $818.9 \mathrm{Da}$ ), by a Michael additive reaction between activated maleimide and a thiol group (Figure 1A). Formation of the desired compound was further confirmed by the MALDI-TOF mass. Peaks of parental DSPE-PEG(2000) maleimide completely vanished and shifted to the right side, at regions approximating the molecular weight of the thiolated RGD peptide (Figure 1B). DSPE-PEG maleimide was not a homogenous polymer compound. The successive members in DSPE-PEG(2000)RGD or DSPE-PEG(2000) maleimide differed in mass by 44 $\mathrm{Da}$ for the ethylene oxide $-\mathrm{CH}_{2} \mathrm{CH}_{2} \mathrm{O}-$ molecular weight.

\section{Characterization of siRNA-loaded liposomes}

The characterization of the liposomes, including particle sizes, zeta potential, and entrapment efficiency, is summarized in Table 1. The mean particle sizes for the $1 \mathrm{~mol} \%$ and 5 mol\% PEGylated liposomes with siRNA were $129.7 \mathrm{~nm}$ and $147.2 \mathrm{~nm}$, respectively. Mean particle size increased slightly by increasing the molar ratio of the PEGylated lipids. In addition, the RGD-PEGylated liposomes with siRNA had larger mean particle sizes than the PEGylated liposomes. The transmission electron microscopic images of the $1 \mathrm{~mol} \%$ PEGylated liposomes and 1 mol\% RGD-PEGylated liposomes showed a similar particle size distribution as measured by the dynamic light scattering method (Figure 2A and B). The siRNA-loaded $1 \mathrm{~mol} \%$ PEGylated liposome had the highest positive zeta potential $(32 \pm 1.34 \mathrm{mV})$ of all the liposomes studied. When a high molar ratio of DSPEPEG(2000) carboxy was incorporated, the zeta potential was reduced to $25.7 \pm 1 \mathrm{mV}$ for the $5 \mathrm{~mol} \%$ PEGylated liposomes. In addition, incorporation with different molar ratios of the synthesized lipid, DSPE-PEG(2000)-RGD, reduced the zeta potential to $24.9 \pm 1.5$ for the $1 \mathrm{~mol} \%$ RGD-PEGylated and to $17.3 \pm 0.6 \mathrm{mV}$ for the $5 \mathrm{~mol} \%$ RGD-PEGylated liposomes. The PEGylated liposomes and RGD-PEGylated liposomes showed high-level siRNA entrapment efficiencies of more than $96 \%$ by the thin film hydration method.

\section{Liposome cytotoxicity}

The cytotoxicity of the liposome formulations was evaluated in the ARPE-19 cells with total liposomal lipid concentrations of $3.2,12.8$, or $51.2 \mu \mathrm{M}$ for the cells incubated with serum-free medium alone, no treatment with liposome as a control, and cell viability set at $100 \%$ (Figure 3 ). The viability of ARPE-19, the group treated with $12.8 \mu \mathrm{M}$ of 1 or $5 \mathrm{~mol} \%$ RGD-PEGylated liposomal suspensions, showed a relative cell viability that remained unchanged. However, there was significantly reduced relative cell viability when the cells were treated with $12.8 \mu \mathrm{M}$ of $1 \mathrm{~mol} \%$ and $5 \mathrm{~mol} \%$ PEGylated liposomes. There was no cytotoxicity among the groups treated with $3.2 \mu \mathrm{M}$, but significant cytotoxicity was observed with the $51.2 \mu \mathrm{M}$ treatment. These results show that RGD peptide modification of cationic PEGylated liposomes was less cytotoxic than the cationic PEGylated liposomes.

\section{CLSM imaging study}

The distribution of FAM-siRNA-loaded liposomes was studied to determine their intracellular distribution with or without DSPE-PEG-RGD. Figure 4 shows the confocal 
A

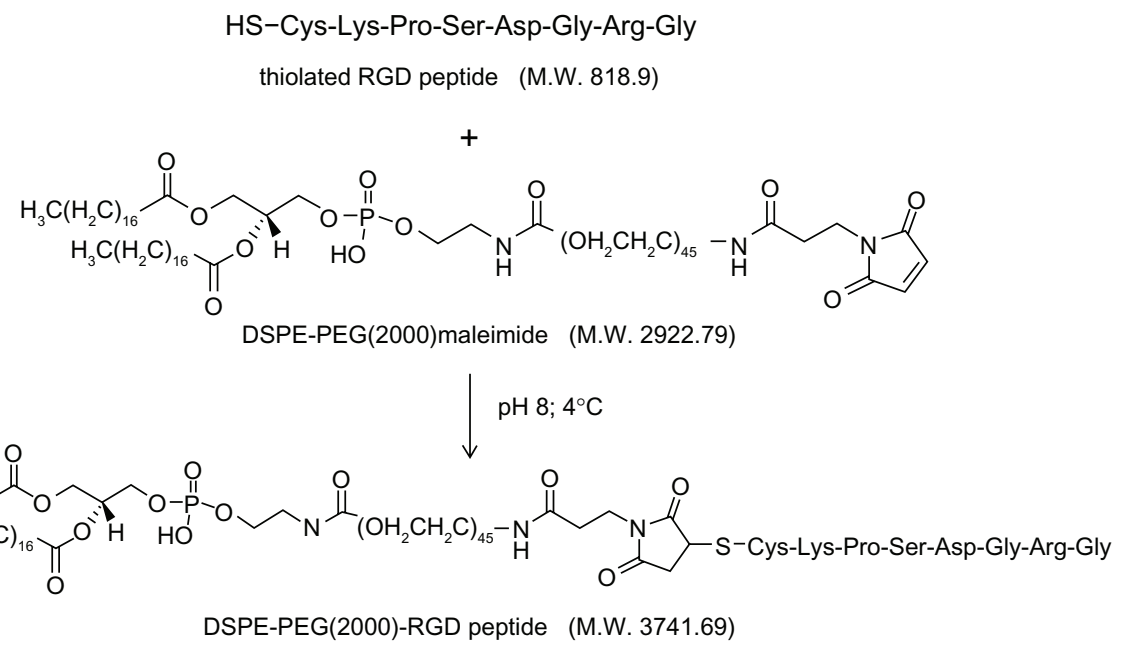

B

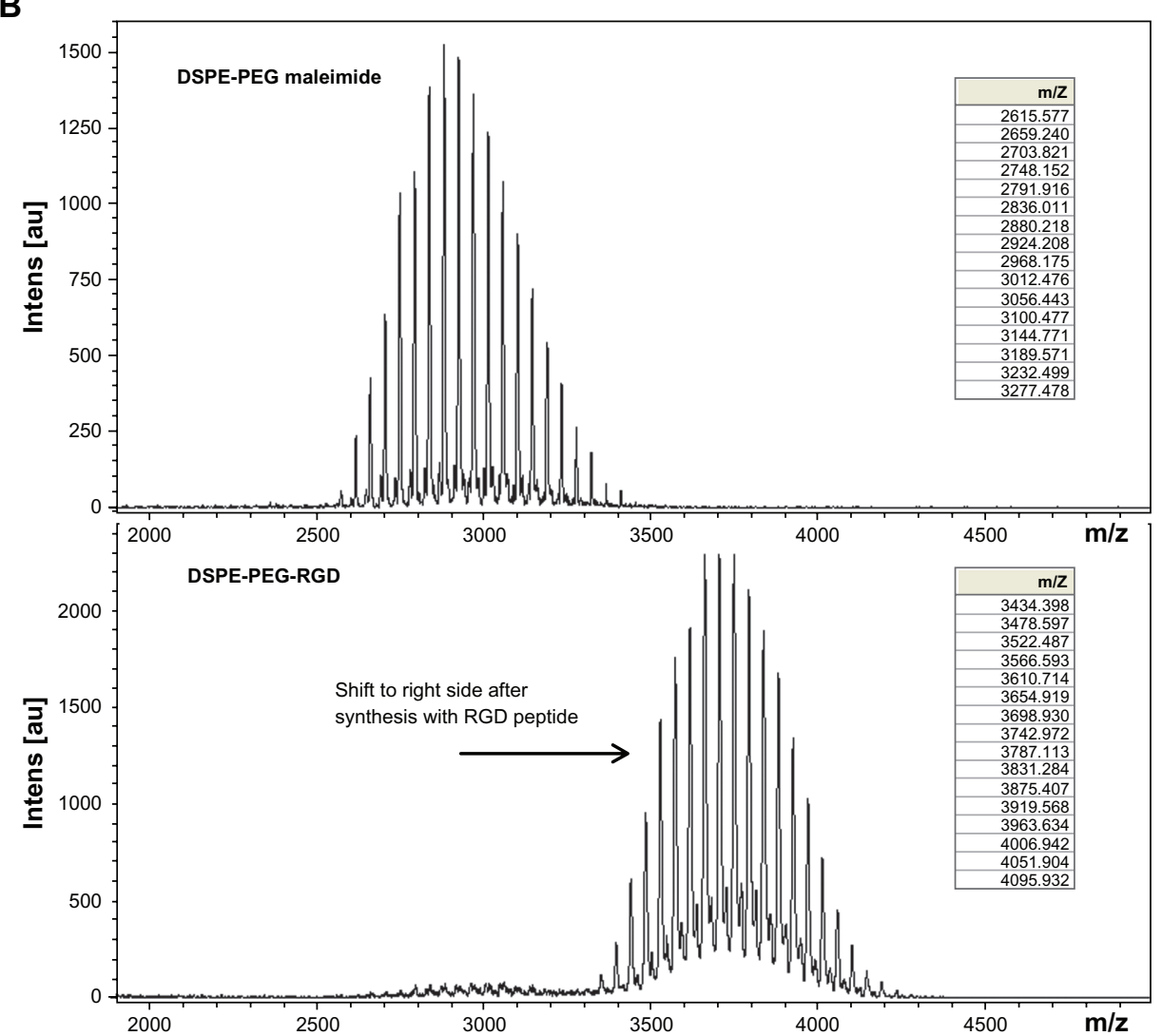

Figure I DSPE-PEG-RGD peptide conjugates (A), Schematic representation of synthesis of DSPE-PEG-RGD peptide conjugates (B) MALDI-TOF mass spectrometric analysis of the DSPE-PEG-RGD conjugate and parental DSPE-PEG maleimide, demonstrating an increase in mass from 2922.79 to 3741.69 after conjugation with the thiolated RGD peptide. This corresponds to one thiolated RGD peptide molecule conjugated to one DSPE-PEG maleimide molecule.

Abbreviations: DSPE-PEG-RGD, $\operatorname{Arg}(\mathrm{R})-\mathrm{Gly}(\mathrm{G})-\operatorname{Asp}(\mathrm{D})$ motif peptide conjugated to I,2-distearoyl-sn-glycero-3-phosphoethanolamine-N-[maleimide (polyethylene glycol)-2000]; MALDI-TOF, matrix-assisted laser desorption/ionization time-of-flight.

images of FAM-siRNA-loaded RGD-PEGylated liposomes; they had a significantly greater amount of speckled green fluorescence (FAM-siRNA) in the ARPE-19 cells compared with the cationic PEGylated liposomes (4B > 4A, 4D > 4C). Slightly more FAM-siRNA was detected in the $1 \mathrm{~mol} \%$ PEGylated liposomes compared with 5 mol\% PEGylated liposomes (4A > 4C). These findings suggest that high levels of PEGylation in the liposomes decreased uptake of FAM-siRNA in the loaded liposomes. However, FAM-siRNA was significantly greater 
Table I Particle characterization of siRNA-loaded liposomes

\begin{tabular}{|c|c|c|c|c|}
\hline Group & Lipid molar ratio in formulation & $\begin{array}{l}\text { Zeta potential } \\
(\mathrm{mV})\end{array}$ & $\begin{array}{l}\text { Mean particle size } \\
(\mathrm{nm})\end{array}$ & $\begin{array}{l}\text { Entrapment } \\
\text { efficiency (\%) }\end{array}$ \\
\hline I mol\% PEGylated liposome & $\begin{array}{l}\text { 50:49:I } \\
\text { (DC-chol/DOPE/DSPE-PEG2000) }\end{array}$ & $32 \pm 1.3^{\ddagger}$ & $\mid 29.7(5 \mid)^{\S}$ & $97.66 \pm 0.05^{\ddagger}$ \\
\hline 5 mol\% PEGylated liposome & $\begin{array}{l}\text { 50:45:5 } \\
\text { (DC-chol/DOPE/DSPE-PEG2000) }\end{array}$ & $25.3 \pm 1$ & I $47.2(48.2)$ & $96.07 \pm 0.07$ \\
\hline I mol\% RGD-PEGylated liposome & $\begin{array}{l}\text { 50:49:I } \\
\text { (DC-chol/DOPE/DSPE-PEG2000-RGD) }\end{array}$ & $24.9 \pm 1.5$ & I56.4 (37.5) & $98.83 \pm 0.01$ \\
\hline 5 mol\% RGD-PEGylated liposome & $\begin{array}{l}\text { 50:45:5 } \\
\text { (DC-chol/DOPE/DSPE-PEG2000-RGD) }\end{array}$ & $17.3 \pm 0.6$ & $230.7(60.7)$ & $99.34 \pm 0.03$ \\
\hline
\end{tabular}

Notes: ${ }^{\circ}$ Data are the mean \pm standard deviation for $n=3 ;{ }^{\S}$ data are the mean (distribution width).

in the $1 \mathrm{~mol} \%$ RGD-PEGylated liposomes compared with the $5 \mathrm{~mol} \%$ RGD-PEGylated liposomes (4B > 4D). A three-dimensional detection method was used by the CLSM for determination of FAM-siRNA loaded liposomes localized within the cell. Comparison of $1 \mathrm{~mol} \%$ PEGylated liposomes with 1 mol\% RGD-PEGylated liposomes (Figure $5 \mathrm{~A}$ and $\mathrm{B}$ ) showed that the $1 \mathrm{~mol} \%$ RGD-PEGylated liposomes were more localized than the $1 \mathrm{~mol} \%$ PEGylated liposomes $(5 \mathrm{~B}>5 \mathrm{~A})$. The total number of $1 \mathrm{~mol} \%$ PEGylated liposomes and 1 mol\% RGD-PEGylated liposomes was counted as 40 and 89 , respectively. These findings suggest that the RGD-PEGylated liposomes may provide an efficient transfer of siRNA for delivery into ARPE-19 cells.

\section{Liposome uptake by ARPE- 19 cells}

The FAM-siRNA uptake intensity in the ARPE-19 cells was studied to evaluate the PEGylated liposomes and RGD-PEGylated liposomes; flow cytometry was used for the analysis. Comparison in the presence and absence of RGD-PEGylated effects in the formulation of $1 \mathrm{~mol} \%$ and
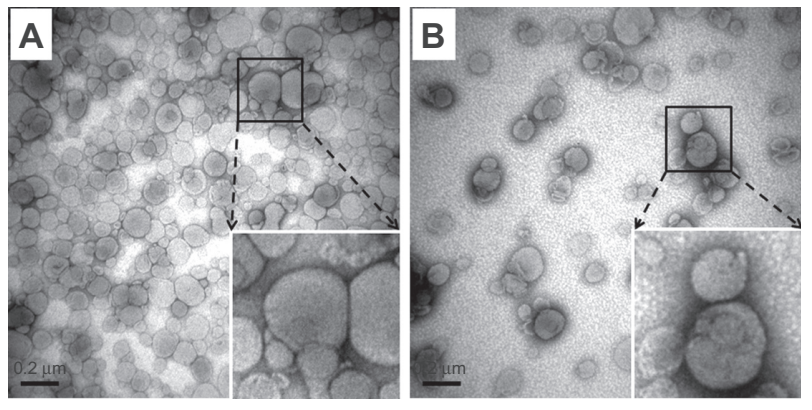

Figure 2 Transmission electron microscopic images of siRNA-loaded liposomes. (A) siRNA-loaded I mol\% PEGylated liposomes. (B) siRNA-loaded I mol\% PEGylated, RGD peptide-modified liposomes. The images were taken at 50,000× magnification from the suspended liposomal particles after negative staining. In the bottom-right corner, the local image was enlarged to view the interface of liposomes clearly. Bar $=0.2 \mu \mathrm{m}$.

Abbreviations: siRNA, small interfering RNA; PEG, polyethylene glycol.
5 mol\% RGD-PEGylated liposomes, showed FAM-siRNA delivery efficiencies of about 3.6 times and 4.2 times greater than for $1 \mathrm{~mol} \%$ and $5 \mathrm{~mol} \%$ PEGylated liposomes, respectively (Figure $6 \mathrm{~B}$ and $\mathrm{C}$ ). For the $1 \mathrm{~mol} \%$ and 5 mol\% PEGylated liposomes, the FAM-siRNA delivery efficiency decreased as the percentage of PEGylated lipids increased in the formulation. In the $1 \mathrm{~mol} \%$ and $5 \mathrm{~mol} \%$ RGD-PEGylated liposomes, the FAM-siRNA delivery efficiency was also decreased as the percentage of DSPEPEG-RGD increased in the formulation. Similar trends were observed in the results of the CLSM imaging study. These findings might be explained by the RGD peptide modification of the PEGylated liposomes enhancing the delivery efficiency of the cargo gene, FAM-siRNA, into the ARPE-19 cells. From the image of the forward and side light scatter, cell debris was significantly observed in the $5 \mathrm{~mol} \%$ PEGylated liposomes, but was not obvious in the $5 \mathrm{~mol} \%$ RGD-PEGylated liposomes. These findings suggest that the cationic PEGylated liposome with a higher percentage of PEGylated-lipids might have damaged the cell integrity (Figure 6A). However, RGD peptide modification of the cationic PEGylated liposomes appears to have reduced damage to the integrity of the cell. These findings suggest that PEGylated lipid interferes with the integrity of the cell and that DSPE-PEG-RGD is less prone to induce cell damage.

\section{Antibody blocking assay}

Comparison of the uptake of FAM-siRNA loaded $1 \mathrm{~mol} \%$ PEGylated liposomes of cells with or without antibody pretreatment; the group without antibody pretreatment was used as a control, and the FAM-siRNA uptake intensity was set at $100 \%$. The pretreatment of anti- $\alpha_{v} \beta_{3},-\alpha_{5} \beta_{1}$, or $-\alpha_{5}$ antibody uptake percentage was decreased to $23.2 \%$ $(P<0.01), 31.9 \%(P<0.001)$, and 34.1\% $(P<0.001)$, respectively (Figure 7 ). When pretreated with a mixture 


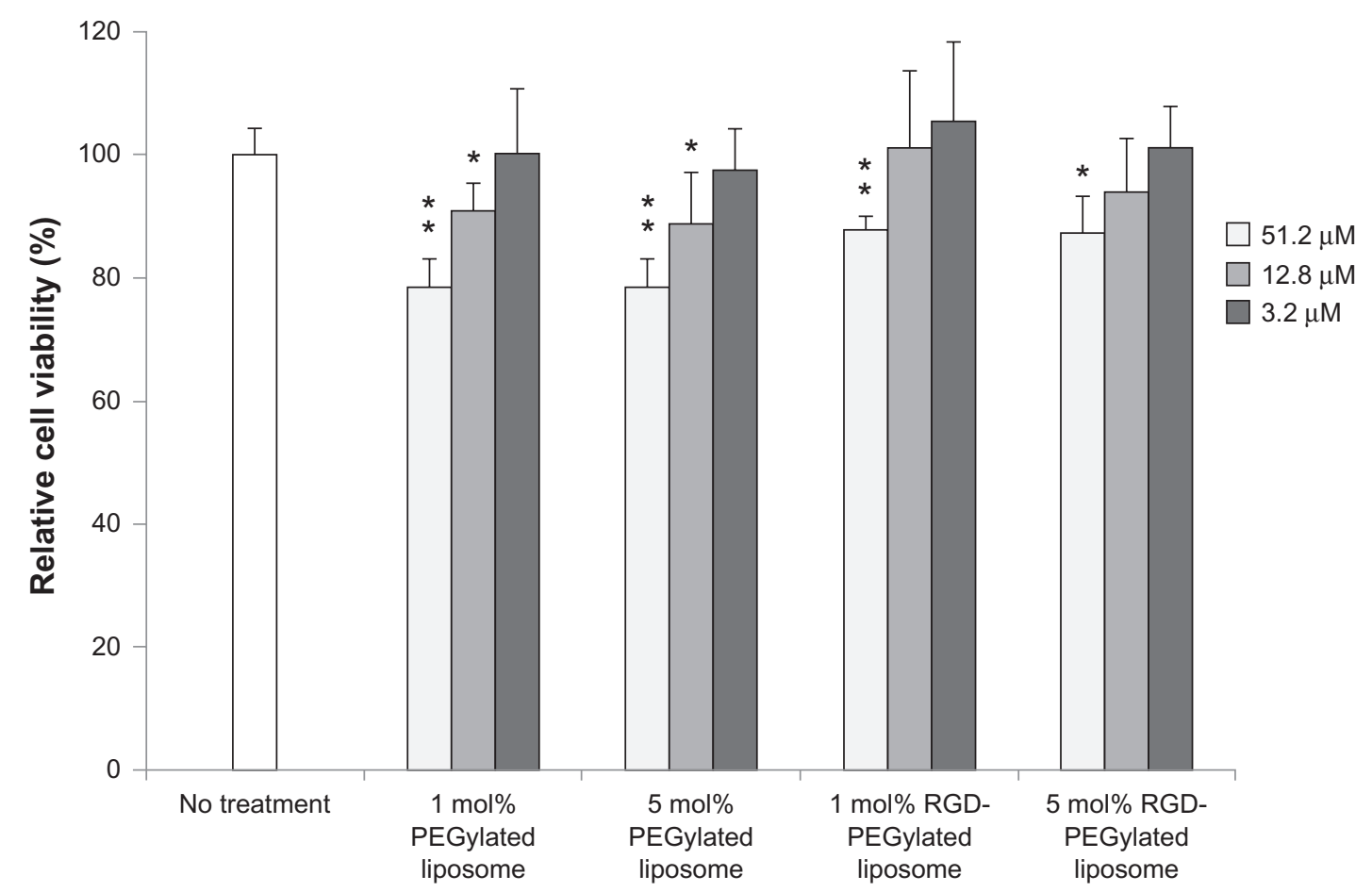

Figure 3 Cell viability of siRNA-loaded liposome preparations in ARPE-19 cells after four hours of treatment: The total lipid concentrations of siRNA-loaded liposome preparations investigated were 5I.2, 12.8, and $3.2 \mu \mathrm{M}$.

Notes: Data are expressed as the mean \pm standard deviation for $n=5$. (Student's $t$-test $* p<0.05$ or $* * p<0.01$ compared with the untreated group).

of $-\alpha_{\mathrm{v}} \beta_{3},-\alpha_{5} \beta_{1}$, and $-\alpha_{5}$ antibodies, the uptake percentage was decreased to $49.5 \%(P<0.001)$ compared with no pretreated antibody control. These data further confirmed that the RGD-PEGylated liposomes were internalized by integrin receptor-mediated endocytosis in ARPE-19 cells.

\section{Discussion}

Because it is difficult for free siRNA to enter into cells, lipid-based carriers are often used to improve cellular uptake of siRNA. ${ }^{26}$ Previous studies have reported that cationic liposomes can be used for gene delivery; they are easy to prepare, reasonably inexpensive, and can achieve ideal transfection. ${ }^{27,28}$ Currently, the targeting liposome design is of great interest for the transport of genes into desired target cells; this method has the potential to produce greater and more selective therapeutic activity. This approach involves the coupling of targeting moieties capable of recognizing target cells, binding to them, and internalization of the liposomes and encapsulated gene. For this process, a variety of targeting liposomes can be developed. For example, an antibody-mediated liposome, or an immunoliposome, can be constructed to target HER2-overexpressing tumors using anti-HER2 liposomes. Other ligands such as folate, transferrin, RGD peptide, and the epidermal growth factor receptor have also been studied. ${ }^{29}$ However, previous studies have usually prepared the nanoparticles first, and then added a targeting molecule for conjugation on the surface of the nanoparticle. ${ }^{17,29,30}$ This method is limited by the difficulty in controlling the number of targeting moieties conjugated to the constructed nanoparticles. In this report, synthesis of the ligand-conjugated lipid, DSPE-PEG-RGD, was performed by Michael addition reactions between activated maleimide and thiol groups prior to preparation of the liposomes (Figure 1A). The DSPE-PEG-RGD was easy to synthesize, allowing precise addition of the targeting molecule in a variety of liposome preparations. In this study, MALDI-TOF mass spectrometry, a powerful tool for identification of a compound's molecular weight, was used to determine the molecular weight of DSPE-PEG maleimide and DSPEPEG-RGD. MALDI-TOF mass spectrometry showed that the DSPE-PEG-RGD peaks all increased approximately 818.9 Da, which is the molecular weight of thiolated RGD peptide, compared with the relative DSPE-PEG maleimide peaks (Figure 1B). After reaction, the parental DSPE-PEG maleimide peaks were almost gone, and instead DSPEPEG-RGD peaks were observed. These results showed that the DSPE-PEG maleimide reacted quantitatively with one thiolated RGD peptide. 

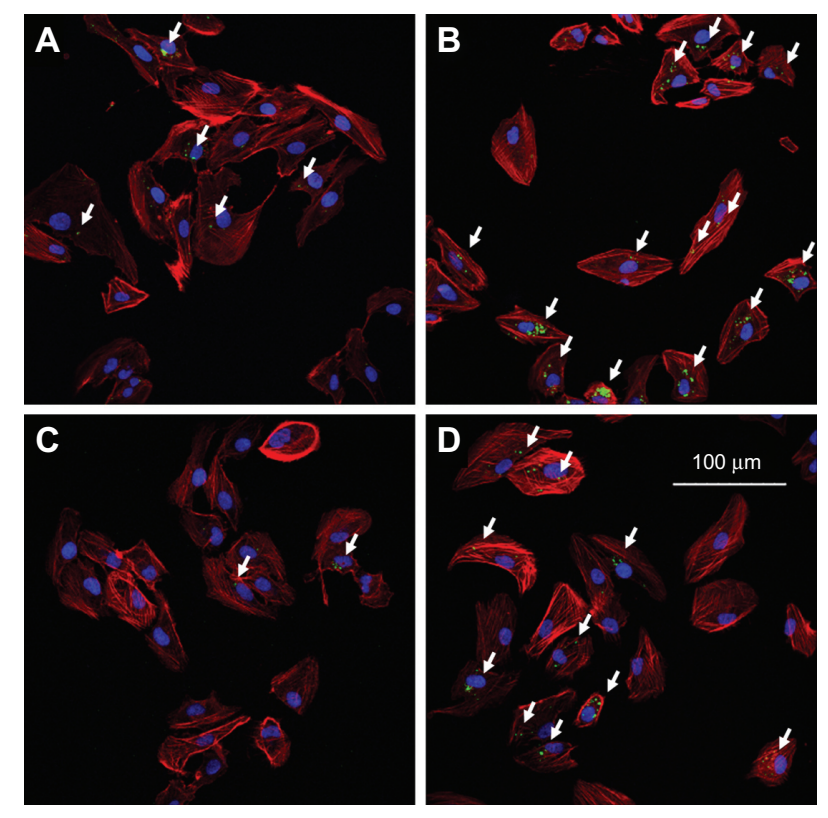

Figure 4 Fluorescence microscopic images showing the internalization of various FAM-siRNA-loaded liposomes in ARPE- 19 cells, four hours after administration, at 40× magnification: (A) I mol\% PEGylated liposomes; (B) I mol\% PEGylated, RGD peptide-modified liposomes; (C) 5 mol\% PEGylated liposomes; (D) 5 mol\% PEGylated, RGD peptide-modified liposomes. SiRNA was labeled with FAM (the arrows are added to point out the green sites), the cell nuclei were stained with Hoechst 33342 (blue), and the cell actin was stained with BODIPY phalloidin (red).

Abbreviations: FAM, fluorescein-labeled; siRNA, small interfering RNA; PEG, polyethylene glycol; RGD, $\operatorname{Arg}(R)-G l y(G)-A s p(D)$ motif peptide.

The PEG moiety of the liposome has been demonstrated to be more stable and remains in the circulation for a longer period of time in vivo, because the PEG moiety provides an efficient steric hindrance that prevents the binding of plasma proteins with the liposomes and thereby also interferes with uptake by the reticuloendothelial system. ${ }^{10,29,31}$ In this study, the zeta potential of the siRNA-loaded $1 \mathrm{~mol} \%$ PEGylated liposome was highly positive $(32 \pm 1.3 \mathrm{mV})$. However, when a high molar ratio of DSPE-PEG was incorporated, it was reduced to $25.3 \pm 1 \mathrm{mV}$ for the $5 \mathrm{~mol} \%$ PEGylated liposomes. Incorporating different molar ratios of DSPEPEG-RGD resulted in further reductions in the zeta potential to $24.9 \pm 1.5$ for the $1 \mathrm{~mol} \%$ RGD-PEGylated liposomes and to $17.3 \pm 0.6 \mathrm{mV}$ for the $5 \mathrm{~mol} \%$ RGD-PEGylated liposomes (Table 1). These findings show that the presence of a lipid-bound PEG moiety shielded the positive charge from the cationic lipid, and the presence of a RGD peptide at the end of PEG moiety shielded the molecule from a more positive charge.

In 1 mol\% PEGylated liposomes and 1 mol\% RGDPEGylated liposomes, the hydrodynamic size was in the range of 129.7 to $156.4 \mathrm{~nm}$, associated with a narrow size distribution of 51 to $37.5 \mathrm{~nm}$, respectively. The presence of the
RGD peptide on the liposome surface slightly increased the size compared with liposomes without the RGD peptide. Theoretically, for a $100 \mathrm{~nm}$ liposomal particle modified with DSPE-PEG2000, the PEG moiety is arranged in the mushroom mode in the presence with $<4$ mol\% DSPE-PEG2000; the PEG moiety is configured in phase transition by the presence of a 4 to $8 \mathrm{~mol} \%$ modification, and in the brush mode with $>8$ mol $\%$ PEGylation..$^{32}$ The effect of grafted PEG on liposome size is mainly a change in the spatial structure of the DSPE-PEG molecule, which is contingent on the grafted PEG in the mushroom or brush configuration. ${ }^{33}$

The transmission electron microscopic assay showed clearly the image of the small unilamellar vesicles that comprise the lipid bilayer, with diameters in the range of 50-250 nm; a narrow size distribution was observed (Figure 2). The small unilamellar vesicles contain a large aqueous core and are preferentially used for encapsulated water-soluble drugs. ${ }^{10}$ These findings indicate that the DSPEPEG-RGD incorporated into the liposome resulted in sterically stabilized liposomes as well as PEGylated liposomes.

In this study, siRNA entrapment efficiencies were all higher than $96 \%$. This was primarily due to the electrostatic interaction between the dimethylaminoethane of the DC-cholesterol and the phosphate groups of the siRNA in a $+/$ - charge ratio of 4 , consistent with previously reported findings from Zhang et al. ${ }^{34}$

Liposomes are composed of phospholipids and cholesterols, which are components of the cell; these compounds are biocompatible and nontoxic particulates that can be used for gene carrier constructs. However, there are some components reported that tend to be associated with cytotoxicity. For example, positively charged liposomes containing DC-cholesterol had increased toxicity when their dimethylaminoethane content was increased ${ }^{35}$ the liposome formulations included a lipid holding a PEG moiety to reduce the surface charge density of the cationic lipid. However, as the PEG molecular weight of the PEGylated nanoparticle increased, the cytotoxicity also increased. ${ }^{36} \mathrm{In}$ this study, the cytotoxicity caused by the RGD-PEGylated liposome was lower than for the PEGylated liposome; these findings suggest that RGD peptide modification reduced the toxicity of the PEG portion of the liposome structure. With the concentration of the RGD-PEGylated liposome in the culture medium less than $12.8 \mu \mathrm{M}$, the biosafety of the delivery system was improved in ARPE-19 cells (Figure 3). Hence, this safe concentration was used in the subsequent siRNA delivery assay. 

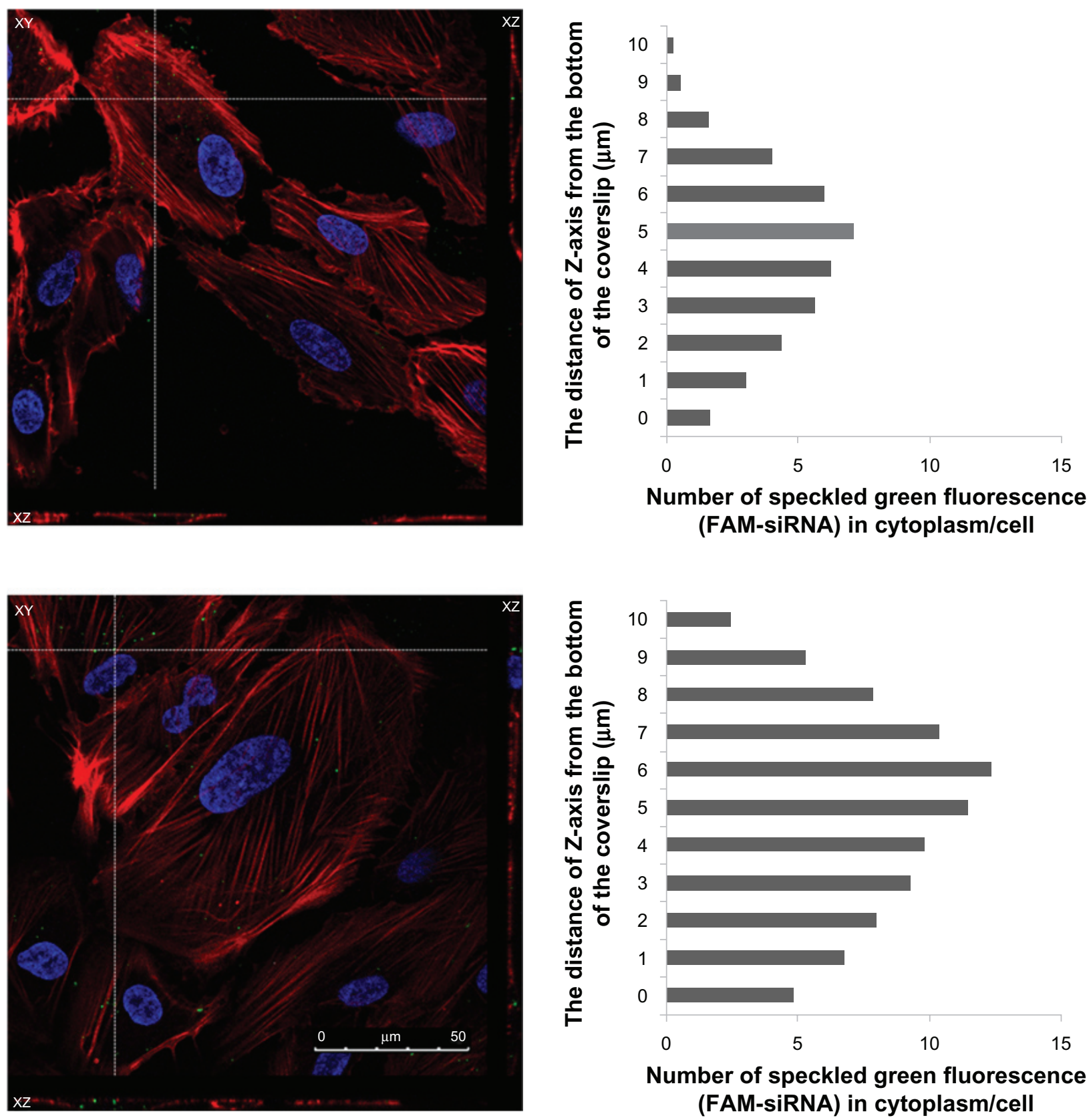

Figure 5 Three-dimensional confocal images showing the intracellular location of FAM-siRNA-loaded liposomes (green) in ARPE-19 cells, four hours after administration, at I00X magnification: I mol\% PEGylated liposomes (top figure); I mol\% RGD-PEGylated liposomes (bottom figure). The number of speckled green fluorescence images of FAMsiRNA located within the cytoplasm were counted at each Z-series image (right of figure). The cell nuclei were stained with Hoechst 33342 (blue), and the cell was stained with BODIPY phalloidin (red).

Abbreviations: FAM, fluorescein-labeled; siRNA, small interfering RNA; RGD, $\operatorname{Arg}(R)-G l y(G)-A s p(D)$ motif peptide.

The liposomal surface charge is considered one of the most important parameters governing cellular uptake of nanoparticles, which occurs by the electrostatic interactions of oppositely charged cells and liposomes. ${ }^{37,38}$ PEGylated liposomes decreased the uptake of the liposome and its cargo gene, FAM-siRNA (Figure 4A and C); this resulted from not only a lower positive charge on the liposome surface, but also the ability of the PEG moiety of the liposome to prevent contact with the cell surface. These properties minimize the nonspecific binding of liposomes to the cell surface. ${ }^{39,40}$ However, in order to accumulate more liposomal siRNA in the retinal pigment epithelial cells, with the goal of producing greater and more selective therapeutic activity, use of active targeted liposomes with the RGD peptide has been suggested. This involves coupling RGD moieties capable of recognizing and binding to the integrin receptor of the retinal pigment epithelial cells, and then inducing liposome or loaded siRNA uptake. The expression of $\alpha_{5} \beta_{1}$ integrins on the basolateral 


\section{A $\quad$ B}

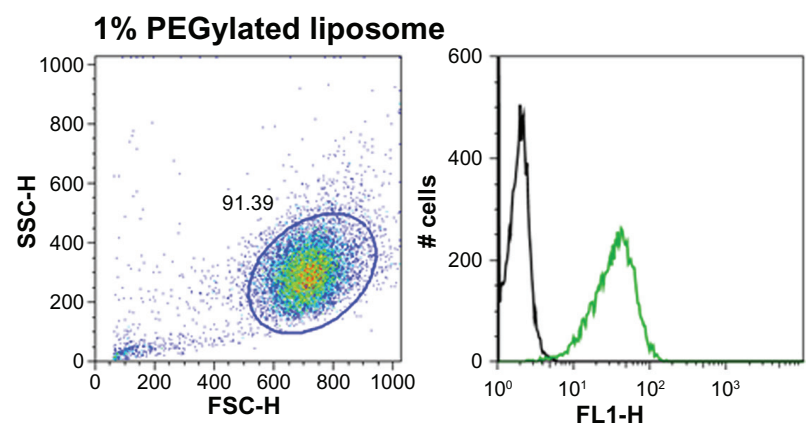

$1 \%$ RGD-PEGylated liposome
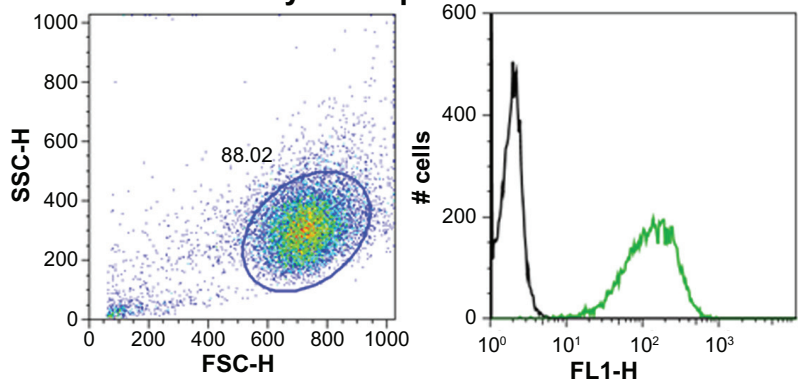

$5 \%$ PEGylated liposome
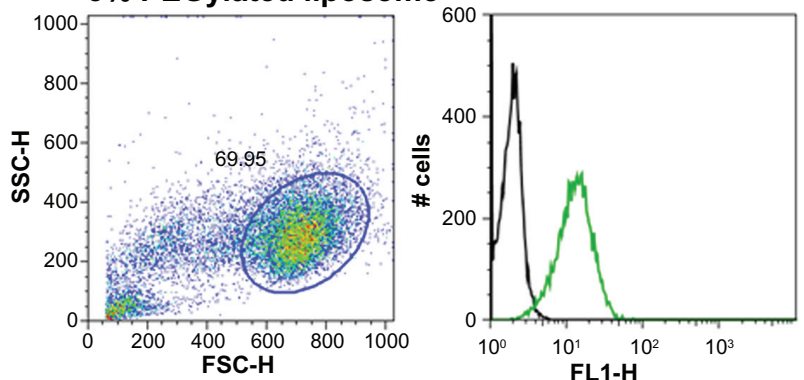

$5 \%$ RGD-PEGylated liposome
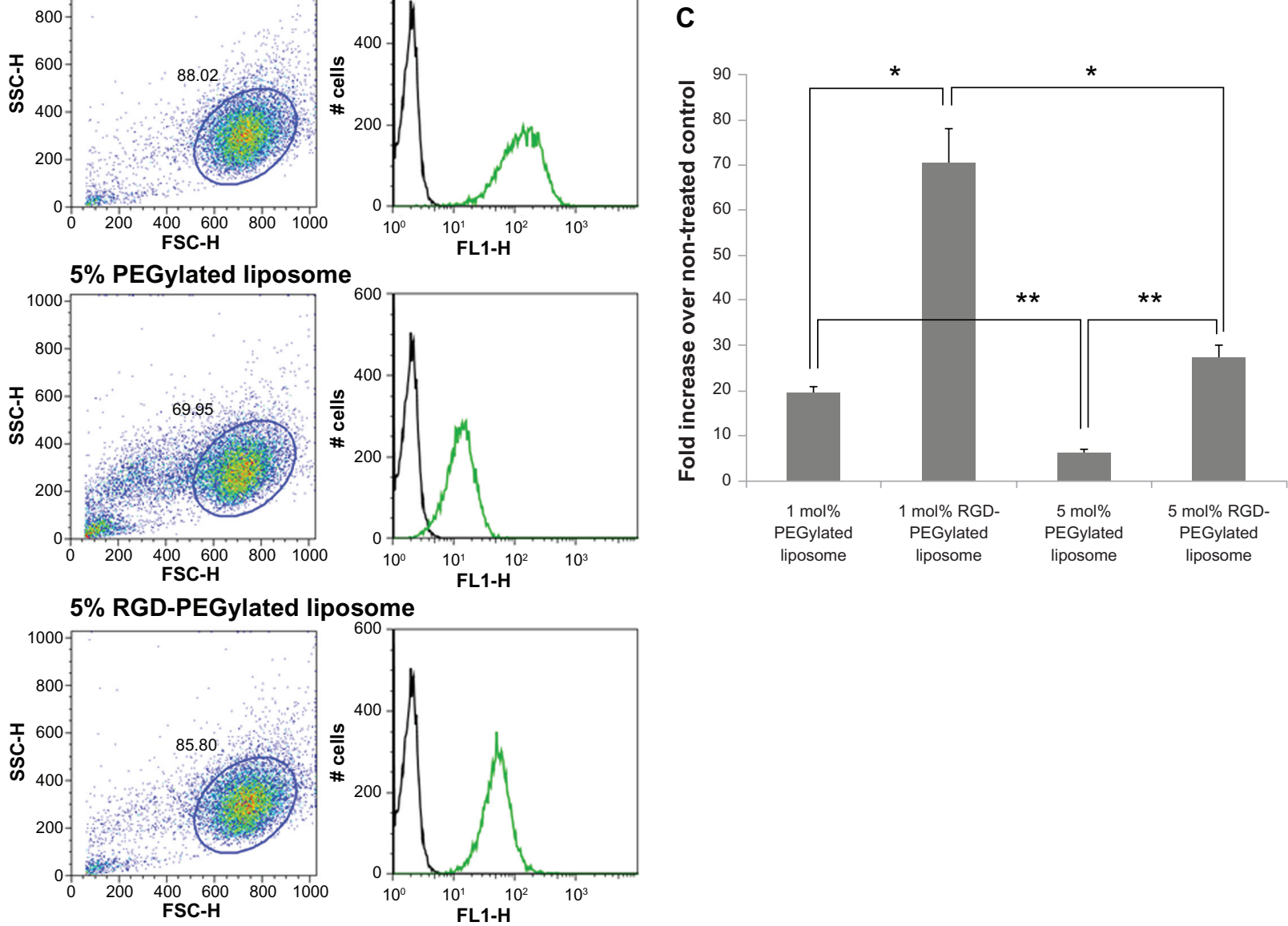

Figure 6 Various amounts of FAM-siRNA loaded liposome uptake as measured by flow cytometry. (A) Forward and side light scatter were used to gate the desired scattered events (normal cells) from dead cells and cell debris. (B) In the normal cells, uptake intensity of FAM-siRNA loaded liposome preparations (green histogram) was compared with the untreated control (block histogram). (C) Fluorescence intensity of FAM-siRNA-loaded liposome preparations in the normal cells expressed as an intensity ratio by dividing by the untreated control.

Notes: Data are expressed as the mean \pm SD for $N=3$. (Student's $t$-test: $* P<0.01$ or $* * P<0.005$, RGD peptide-modified liposomes compared with non-RGD peptidemodified liposomes; 5 mol\% compared with I mol\%).

Abbreviations: FAM, fluorescein-labeled; siRNA, small interfering RNA; SD, standard deviation.

side of retinal pigment epithelial cells has been characterized, and shown to be important for attachment of cells to Bruch's membrane, while expression of the $\alpha_{\mathrm{v}} \beta_{3}$ and $\alpha_{\mathrm{v}} \beta_{5}$ integrins on the apical side maintains diurnal phagocytosis of the shed outer segment fragment of the photoreceptor. ${ }^{14}$ The RGD-containing peptide could be used as a specific ligand for integrin $\alpha_{\mathrm{v}} \beta_{3}, \alpha_{\mathrm{v}} \beta_{5}$, or $\alpha_{5} \beta_{1}$. Therefore, the synthesized DPSE-PEG-RGD was used to formulate targeted liposomes in this study by covalent binding of the active maleimide of the PEG end and the specific thiol group of ligands.

For the siRNA, the interference mechanism is necessary for successful delivery of siRNA into the cytoplasm 


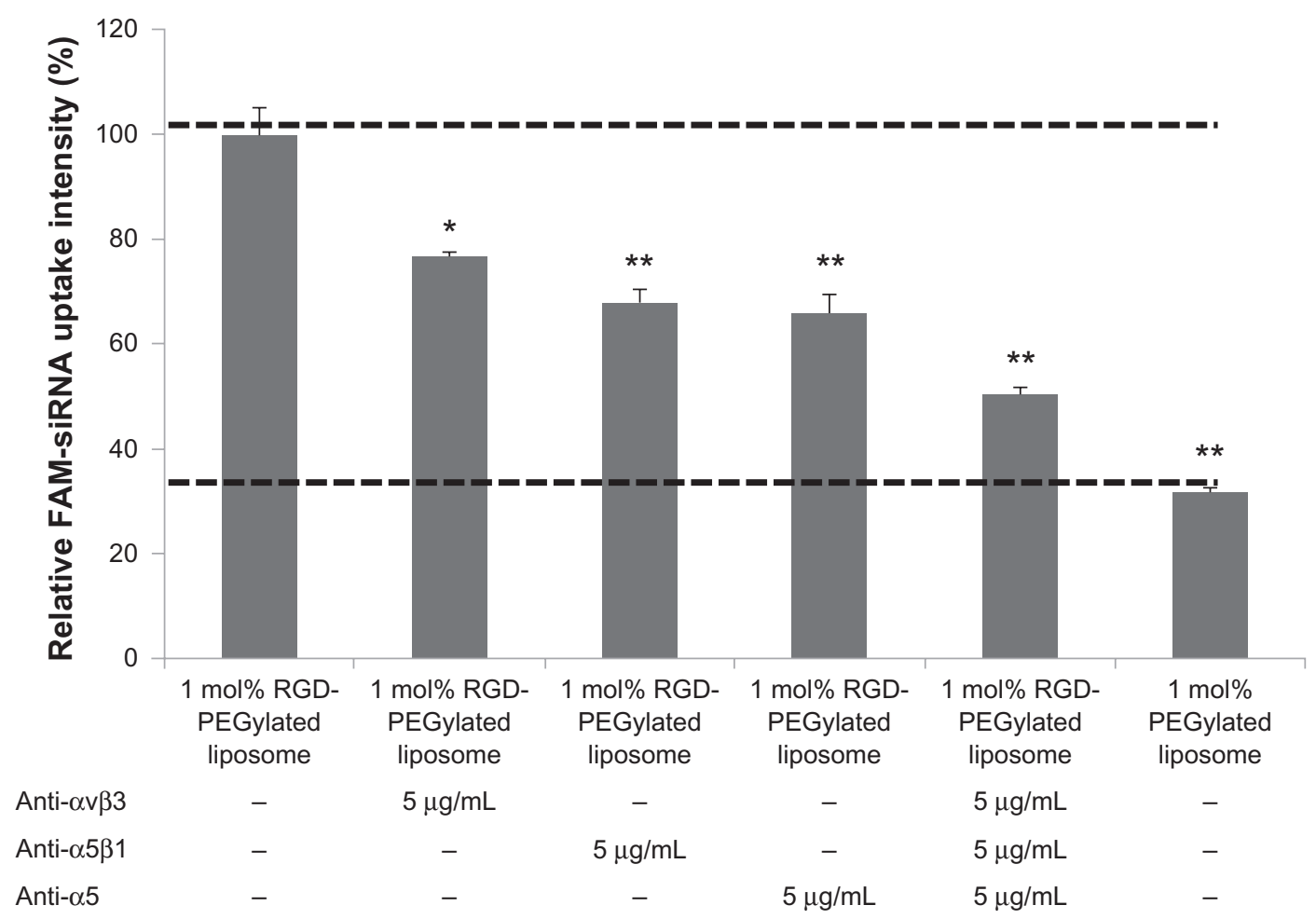

Figure 7 Effect of antibodies on cell integrin receptors and uptake of I mol\% RGD-PEGylated liposomes by ARPE- I9 cells: The cells were incubated with FAM-siRNA -loaded I mol\% PEGylated liposomes after one hour of blocking with antibody.

Notes: Data are expressed as the mean \pm standard deviation for $n=4$. (Student's $t$-test $* P<0.01$, or $* * P<0.00$ I, compared with I mol\% RGD-PEGylated liposomes, no antibody blocking control.)

Abbreviations: FAM, fluorescein-labeled; siRNA, small interfering RNA; RGD, $\operatorname{Arg}(R)-G l y(G)-A s p(D)$ motif peptide; PEG, polyethylene glycol.

of target cells. In further analysis of the CLSM images, comparing the $1 \mathrm{~mol} \%$ RGD-PEGylated liposomes with the $1 \mathrm{~mol} \%$ PEGylated liposomes, the total number of 1 mol\% RGD-PEGylated liposomes localized within the cells was more than for the $1 \mathrm{~mol} \%$ PEGylated liposomes (Figure 5A and B). Therefore, a large amount of the FAM-siRNA-loaded 1 mol\% RGD-PEGylated liposomes was confirmed to provide effective delivery into the cytoplasm of the ARPE-19 cells. However, siRNA delivery is a multistep process, which has several potential problems, including biological barriers to penetration, cellular internalization, endosomal escape, and cytoplasm trafficking. ${ }^{5,34}$ In the future, the knockdown effect of targeted liposomes encapsulating a functional siRNA and the therapeutic effects in vivo of targeted delivery will require further evaluation.

Previous reports have shown that a suitable size and positive zeta potential are essential for enhanced delivery of particles into cells. ${ }^{41}$ The results of this study show that RGD-PEGylated liposomes have a larger size and smaller zeta potential, but increased siRNA delivery efficiency in ARPE-19 cells, compared with PEGylated liposomes
(Figure 6). Demonstrating further that binding was mediated by RGD-associated integrin receptors, the data from the integrin $-\alpha_{\mathrm{v}} \beta_{3},-\alpha_{5} \beta_{1}$, and $-\alpha_{5}$ antibody blocking assay showed that RGD-modified PEGylated liposomes were internalized by integrin receptor-mediated endocytosis in the retinal pigment epithelial cells. However, the fluorescence of FAM-siRNA-loaded 1 mol\% RGD-PEGylated liposomes was not completely inhibited by pretreating the cells with blocking antibodies against $\alpha_{v} \beta_{3}, \alpha_{5} \beta_{1}$, and $\alpha_{5}$ integrins (Figure 7). The integrin family includes not only $\alpha_{\mathrm{v}} \beta_{3}$ and $\alpha_{5} \beta_{1}$, but also $\alpha_{8} \beta_{1}, \alpha_{11 b} \beta_{3}, \alpha_{v} \beta_{6}$, and $\alpha_{v} \beta_{8}$, which recognize RGD-containing peptides. ${ }^{42}$

\section{Conclusion}

The results of this study showed successful synthesis of the functional lipid, DSPE-PEG-RGD, which could be incorporated into a liposome formulation that was prepared and loaded with siRNA for effective delivery into ARPE-19 cells. The prepared siRNA-loaded $1 \mathrm{~mol} \%$ RGD-PEGylated liposomes demonstrated a positive charge $(24.9 \pm 1.5 \mathrm{mV})$, a nanosize of $156.4 \mathrm{~nm}$ (with narrow distribution width of $37.5 \mathrm{~nm})$, entrapment efficiency $(98.83 \% \pm 0.01 \%)$, 
low cytotoxicity, and a high level of siRNA delivery efficiency compared with other investigated liposome vehicles. The antibody blocking assay results confirm that receptor-mediated endocytosis was involved in the cell uptake of the RGD-PEGylated liposomes and the loaded siRNA. These results provide a methodology for siRNAspecific delivery to retinal pigment epithelial cells using RGD-modified PEGylated liposomes.

\section{Acknowledgments}

This research was partly supported by a National Science Council grant (99-2320-B-016-004-MY2 to C-H Chiang) and Tri-Service General Hospital (TSGH C99-086 to D-W $\mathrm{Lu}$ ), Taiwan. We are grateful to the staff of TC5 Bio-Image Tools (Technology Commons, College of Life Science, National Taiwan University) for their assistance with confocal laser scanning microscopy and transmission electron microscopy.

\section{Disclosure}

The authors report no conflicts of interest in this work.

\section{References}

1. Zabner J. Cationic lipids used in gene transfer. Adv Drug Deliv Rev. 1997;27(1):17-28.

2. Liu F, Huang L. Development of non-viral vectors for systemic gene delivery. J Control Release. 2002;78(1-3):259-266.

3. Dass CR, Choong PF. Selective gene delivery for cancer therapy using cationic liposomes: in vivo proof of applicability. J Control Release. 2006;113(2):155-163.

4. Dykxhoorn DM, Novina CD, Sharp PA. Killing the messenger: short RNAs that silence gene expression. Nat Rev Mol Cell Biol. 2003;4(6):457-467.

5. de Fougerolles A, Vornlocher HP, Maraganore J, Lieberman J. Interfering with disease: a progress report on siRNA-based therapeutics. Nat Rev Drug Discov. 2007;6(6):443-453.

6. Whitehead KA, Langer R, Anderson DG. Knocking down barriers: advances in siRNA delivery. Nat Rev Drug Discov. 2009;8(2):129-138.

7. Castanotto D, Rossi JJ. The promises and pitfalls of RNA-interferencebased therapeutics. Nature. 2009;457(7228):426-433.

8. Gao Y LX, Li XR. Research progress on siRNA delivery with nonviral carriers. Int J Nanomedicine. 2011;6(1):1017-1025

9. Ewert KK, Zidovska A, Ahmad A, et al. Cationic liposome-nucleic acid complexes for gene delivery and silencing: pathways and mechanisms for plasmid DNA and siRNA. Top Curr Chem. 2010; 296:191-226.

10. Immordino ML, Dosio F, Cattel L. Stealth liposomes: review of the basic science, rationale, and clinical applications, existing and potential. Int J Nanomedicine. 2006;1(3):297-315.

11. Wu SY, McMillan NA. Lipidic systems for in vivo siRNA delivery. AAPS J. 2009;11(4):639-652.

12. Friedlander M, Theesfeld CL, Sugita M, et al. Involvement of integrins alpha v beta 3 and alpha v beta 5 in ocular neovascular diseases. Proc Natl Acad Sci U S A. 1996;93(18):9764-9769.

13. Anderson DH, Johnson LV, Hageman GS. Vitronectin receptor expression and distribution at the photoreceptor-retinal pigment epithelial interface. J Comp Neurol. 1995;360(1):1-16.
14. Lin H, Clegg DO. Integrin alphavbeta5 participates in the binding of photoreceptor rod outer segments during phagocytosis by cultured human retinal pigment epithelium. Invest Ophthalmol Vis Sci. 1998;39(9):1703-1712.

15. Hynes RO. Integrins: bidirectional, allosteric signaling machines. Cell. 2002;110(6):673-687.

16. Dunehoo AL, Anderson M, Majumdar S, Kobayashi N, Berkland C, Siahaan TJ. Cell adhesion molecules for targeted drug delivery. J Pharm Sci. 2006;95(9):1856-1872.

17. Rivest V, Phivilay A, Julien C, et al. Novel liposomal formulation for targeted gene delivery. Pharm Res. 2007;24(5):981-990.

18. Meure LA, Foster NR, Dehghani F. Conventional and dense gas techniques for the production of liposomes: a review. AAPS Pharm Sci Tech. 2008;9(3):798-809.

19. Khatri K, Goyal AK, Gupta PN, Mishra N, Mehta A, Vyas SP. Surface modified liposomes for nasal delivery of DNA vaccine. Vaccine. 2008;26(18):2225-2233.

20. Tiwari S, Goyal AK, Mishra N, et al. Development and characterization of novel carrier gel core liposomes based transmission blocking malaria vaccine. J Control Release. 2009;140(2):157-165.

21. Chen JT, Liang JB, Chou CL, et al. Glucosamine sulfate inhibits TNF-alpha and IFN-gamma-induced production of ICAM-1 in human retinal pigment epithelial cells in vitro. Invest Ophthalmol Vis Sci. 2006; 47(2):664-672.

22. Ye Y, De Leon J, Yokoyama N, Naidu Y, Camerini D. DBR1 siRNA inhibition of HIV-1 replication. Retrovirology. 2005;2:63.

23. Morales SA, Mareninov S, Prasad P, Wadehra M, Braun J, Gordon LK. Collagen gel contraction by ARPE-19 cells is mediated by a FAK-Src dependent pathway. Exp Eye Res. 2007;85(6):790-798.

24. Bejjani RA, BenEzra D, Cohen H, et al. Nanoparticles for gene delivery to retinal pigment epithelial cells. Mol Vis. 2005;11:124-132.

25. Zhao MW, Jin ML, He S, Spee C, Ryan SJ, Hinton DR. A distinct integrin-mediated phagocytic pathway for extracellular matrix remodeling by RPE cells. Invest Ophthalmol Vis Sci. 1999;40(11):2713-2723.

26. Pirollo KF, Chang EH. Targeted delivery of small interfering RNA: approaching effective cancer therapies. Cancer Res. 2008; 68(5):1247-1250.

27. Audouy S, Hoekstra D. Cationic lipid-mediated transfection in vitro and in vivo (review). Mol Membr Biol. 2001;18(2):129-143.

28. Montier T, Benvegnu T, Jaffres PA, Yaouanc JJ, Lehn P. Progress in cationic lipid-mediated gene transfection: a series of bio-inspired lipids as an example. Curr Gene Ther. 2008;8(5):296-312.

29. Torchilin VP. Recent advances with liposomes as pharmaceutical carriers. Nat Rev Drug Discov. 2005;4(2):145-160.

30. Singh SR, Grossniklaus HE, Kang SJ, Edelhauser HF, Ambati BK, Kompella UB. Intravenous transferrin, RGD peptide and dual-targeted nanoparticles enhance anti-VEGF intraceptor gene delivery to laserinduced CNV. Gene Ther. 2009;16(5):645-659.

31. Maruyama K. Intracellular targeting delivery of liposomal drugs to solid tumors based on EPR effects. Adv Drug Deliv Rev. 2011;18;63(3): 161-169.

32. Li SD, Huang L. Stealth nanoparticles: high density but sheddable PEG is a key for tumor targeting. J Control Release. 2010;145(3):178-181.

33. Garbuzenko O, Barenholz Y, Priev A. Effect of grafted PEG on liposome size and on compressibility and packing of lipid bilayer. Chem Phys Lipids. 2005;135(2):117-129.

34. Zhang Y, Li H, Sun J, et al. DC-Chol/DOPE cationic liposomes: a comparative study of the influence factors on plasmid pDNA and siRNA gene delivery. Int J Pharm. 2010;390(2):198-207.

35. Morille M, Passirani C, Vonarbourg A, Clavreul A, Benoit JP. Progress in developing cationic vectors for non-viral systemic gene therapy against cancer. Biomaterials. 2008;29(24-25):3477-3496.

36. He L, Yang L, Duan Y, et al. Cytotoxicity and hemocompatibility of a family of novel MeO-PEG-poly (D,L-lactic-co-glycolic acid)PEG-OMe triblock copolymer nanoparticles. J Appl Polym Sci. 2009; 113(5):2933-2944. 
37. Miller CR, Bondurant B, McLean SD, McGovern KA, O’Brien DF. Liposome-cell interactions in vitro: effect of liposome surface charge on the binding and endocytosis of conventional and sterically stabilized liposomes. Biochemistry. 1998;37(37):12875-12883.

38. Simoes S, Filipe A, Faneca H, et al. Cationic liposomes for gene delivery. Expert Opin Drug Deliv. 2005;2(2):237-254.

39. Dan N. Effect of liposome charge and PEG polymer layer thickness on cell-liposome electrostatic interactions. Biochim Biophys Acta. 2002;1564(2):343-348.
40. Jung SH, Seong H, Cho SH, Jeong KS, Shin BC. Polyethylene glycolcomplexed cationic liposome for enhanced cellular uptake and anticancer activity. Int J Pharm. 2009;382(1-2):254-261.

41. Foged C, Brodin B, Frokjaer S, Sundblad A. Particle size and surface charge affect particle uptake by human dendritic cells in an in vitro model. Int J Pharm. 2005;298(2):315-322.

42. Takagi J, Strokovich K, Springer TA, Walz T. Structure of integrin alpha5beta1 in complex with fibronectin. EMBO J. 2003;22(18): 4607-4615.

\section{Publish your work in this journal}

The International Journal of Nanomedicine is an international, peerreviewed journal focusing on the application of nanotechnology in diagnostics, therapeutics, and drug delivery systems throughout the biomedical field. This journal is indexed on PubMed Central, MedLine, CAS, SciSearch $\AA$, Current Contents ${ }^{\circledR} /$ Clinical Medicine,
Journal Citation Reports/Science Edition, EMBase, Scopus and the Elsevier Bibliographic databases. The manuscript management system is completely online and includes a very quick and fair peer-review system, which is all easy to use. Visit http://www.dovepress.com/ testimonials.php to read real quotes from published authors. 